\title{
The relationship of diet to serum cholesterol levels in young men in Antarctica
}

\author{
By D. L. EASTY* \\ Division of Human Physiology, National Institute for Medical Research, \\ Medical Research Council, Hampstead, London, $\mathrm{NW}_{3}$
}

(Received 29 fuly 1969-Accepted 22 September 1969)

\begin{abstract}
1. Regular estimations of dietary intake, body-weight, skinfold thickness, blood pressure and pulse rate, and serum lipids were made in twenty-four members of an Antarctic expedition over I year.

2. The mean levels of serum total cholesterol, phospholipids, and triglycerides were I $98.5 \pm 4.85 \mathrm{mg} / 100 \mathrm{ml}, 22 \mathrm{I} \cdot 4 \pm 5.73 \mathrm{mg} / 100 \mathrm{ml}$ and $120.9 \pm 13.53 \mathrm{mg} / \mathrm{I} 00 \mathrm{ml}$ respectively. 3. A positive correlation was found between the total intake of fat expressed as calories and the following serum lipid levels: total cholesterol, $\beta$-cholesterol, and the cholesterol:phospholipid ratio. Significant positive correlation was also found between the latter serum levels and fat when expressed as a percentage of the total food intake.

4. This correlation has not been found in small groups before, and is due to the fact that each estimation was the result of several assessments made over I year.

5. The survey suggests that the personal serum cholesterol level may be dependent upon the habitual total intake of dietary fat and the percentage of the total calories supplied by fat.
\end{abstract}

An approximate relationship between ischaemic heart disease and dietary fat through the influence of the latter upon the serum cholesterol level has been known for some time. These reports have related to comparison of diet and heart disease in large population groups. It has been found that there is a positive correlation between the amount of fat consumed and the levels of the blood lipids; those groups subsisting on a low consumption of saturated fat usually have low serum cholesterol levels and suffer a low rate of coronary artery disease, and conversely. In studies involving smaller groups of subjects, it has often been difficult to establish a direct correlation between the fat intake and the serum lipid levels between individuals and this has thrown some doubt on the dietary fat-ischaemic heart disease hypothesis (Morris, Marr, Heady, Mills \& Pilkington, 1963). Further, though the intra-individual variation of dietary fat intake and serum lipid levels has been well investigated, positive correlations have been difficult to substantiate (Antonis, Bersohn, Plotkin, Easty \& Lewis, 1965).

The value of Antarctic expeditions to medical science has lately been realized. The search for changes due to acclimatization in expedition personnel has been abated owing to the low level of exposure to cold that in fact occurs (Norman, 1965) in favour of studies that are not necessarily affected by low temperatures. An isolated and static Antarctic expedition, which today is more civilized than is often realized, provides the opportunity for variables such as the food intake, physical activity, body-weight, and many other criteria to be accurately measured over a prolonged period of time

* Present address: Moorfields Eye Hospital, City Road, London, EC I. 
(Lewis \& Masterson, 1963 ). This paper reports work performed in Antarctica utilizing these advantages. The experiment was designed to investigate dietary food intake and serum lipids in a group of men over a period of 12 months.

\section{EXPERIMENTAL}

The subjects were members of the 196I-2 expedition of the British Antarctic Survey to Halley Bay situated at the base of the Weddel Sea $\left(75^{\circ} 36^{\prime} \mathrm{S} ; 26^{\circ} 39^{\prime} \mathrm{W}\right)$.

The experiment began in February $196 \mathrm{I}$ and ended in January 1962. The average outside temperature for the year was $-19.5^{\circ}$ and the mean wind velocity was about Io knots. Owing to the extreme cold of the winter months, which lasted from May to September, the activity at this time was reduced to a minimum. The average environmental temperature of the living quarters was approximately $20^{\circ}$ throughout the year.

The expedition was composed of twenty-four young adult males of average age $25^{\circ} \circ$ years (range $22-34$ years), average height $178.7 \mathrm{~cm}$ (range $165^{\circ} 9^{-194} \cdot{ }^{\circ}$ ) and of average body-weight $76.6 \mathrm{~kg}$, ranging between 60.4 and $100.5 \mathrm{~kg}$. The men could be classified into groups according to their occupation, namely manual workers (six subjects), scientists (nine subjects), technicians (seven subjects,) and cooks (two subjects).

The diet of the expedition was composed almost entirely of tinned and dehydrated foods, and apart from this characteristic did not vary from the normal diet that would have been expected in the United Kingdom. Fresh meat was eaten at weekly intervals throughout the year. Seal or penguin meat was sometimes eaten but not in great enough quantities to affect the serum lipid levels to any significant extent.

The following variables were measured in the subjects over a period of 12 months: body-weight, total calorie intake and its chemical composition, mean skinfold thickness, blood pressure and pulse rate, serum total lipids, total fatty acids, phospholipids, total cholesterol, cholesterol esters and free cholesterol, $\alpha$ - and $\beta$-cholesterol, the cholesterol: phospholipid ratio and the serum triglycerides.

The dietary survey was performed by the direct method of weighing all the food eaten in a $24 \mathrm{~h}$ period. The calorie equivalents were obtained from the tables of McCance \& Widdowson (1946). In all, two hundred estimations were made.

An assessment was also made of the body-weight and skinfold thickness at monthly intervals. These increased up to the end of the and and 3 rd months respectively, and thereafter remained stable. The average increase in body-weight in the first 2 months was $2.5 \mathrm{~kg}$. Blood pressures and pulse rates were measured at regular intervals. The assessments were made before the subjects rose in the morning on the same day as blood was drawn for the lipid studies. There was no seasonal change, and values were within normal limits for all subjects.

\section{Determination of serum lipids}

Samples of blood were drawn after an overnight fast of $\mathrm{I} O \mathrm{~h}$ and allowed to clot at room temperature. After centrifugation the serum was stored in deep freeze at $-10^{\circ}$. DL- $\alpha$-Tocopherol was added as an antioxidant, and the specimens were stored 
under nitrogen for periods of up to 15 months. Whilst it was not possible to analyse serum specimens in Antarctica immediately after they were taken, in order to assess whether their lipid content was identical before and after storage for I year, serum was similarly treated and stored at $-10^{\circ}$ in our laboratory and analysis at a later date failed to show any deterioration. It was therefore assumed that the precautions described were adequate.

Triglycerides were measured on phospholipid-free extracts directly according to a fluorimetric procedure (Mendelsohn \& Antonis, 1961), and indirectly by the ester group method of Antonis (1959-60). Correlation was good with an average error of $4.1 \mathrm{mg} / \mathrm{I} 00 \mathrm{ml}$ serum. Free and total cholesterol were determined by the method of Sperry \& Webb (1950). Cholesterol was also determined according to the method of Pearson, Stern \& McGavack (1953) on the $\beta$-lipoproteins obtained from serum by separation with heparin according to the procedure of Burstein \& Samaille (1958). Phospholipids were measured by the method of Fiske \& Subbarow (1925).

\section{RESULTS}

The individual mean values for all measurements are shown in Table $\mathrm{r}$. The average food intake for the whole of the year was $3597 \pm 128.9 \mathrm{kcal} / \mathrm{man}$ per day; of this intake, I $2 \cdot 1 \%$ was from protein, $39.8 \%$ came from fat, and $48 \cdot \mathrm{I} \%$ came from carbohydrate.

Table 1. Food intake and serum lipid levels in twenty-four male adults in Antarctica with inter-and intra-individual standard errors

\begin{tabular}{|c|c|c|c|}
\hline & Mean & $\begin{array}{l}\text { Inter-individual } \\
\text { standard error }\end{array}$ & $\begin{array}{l}\text { Intra-individual } \\
\text { standard error }\end{array}$ \\
\hline Age (years) & 25 & 0.53 & - \\
\hline Body-weight (kg) & $76 \cdot 6$ & $2 \cdot 21$ & 0.27 \\
\hline Height $(\mathrm{cm})$ & $178 \cdot 7$ & $I \cdot 32$ & - \\
\hline Total calorie intake (kcal/man day) & 3597 & $128 \cdot 9$ & $131 \cdot 8$ \\
\hline Protein $(\%)$ & $12 \cdot 1$ & 0.25 & 0.22 \\
\hline Fat $(\%)$ & $39 \cdot 8$ & 0.62 & 0.62 \\
\hline Carbohydrate $(\%)$ & $48 \cdot 1$ & 0.68 & 0.58 \\
\hline Mean skinfold thickness ( $\mathrm{mm}$ ) & $9 \cdot 8$ & 0.93 & - \\
\hline Total lipids (mg/100 ml serum) & 65377 & $2 I \cdot 73$ & $\mathbf{I} \cdot \infty$ \\
\hline Total fatty acids (mg/roo $\mathrm{ml}$ serum) & $380 \cdot 2$ & $8 \cdot 18$ & $7 \cdot 16$ \\
\hline Phospholipids (mg/too ml serum) & $22 \mathrm{I} \cdot 4$ & $5 \cdot 73$ & $3 \cdot 10$ \\
\hline Total cholesterol (mg/100 ml serum) & $198 \cdot 5$ & $4 \cdot 85$ & $2 \cdot 65$ \\
\hline Cholesteryl esters (mg//00 $\mathrm{ml}$ serum) & $149 \cdot 8$ & $4 \cdot 10$ & $2 \cdot 26$ \\
\hline Free cholesterol (mg/roo ml serum) & $48 \cdot 7$ & $1 \cdot 73$ & 0.93 \\
\hline$\alpha-C h o l e s t e r o l(\mathrm{mg} / \mathrm{r}$ oo $\mathrm{ml}$ serum) & 347 & $1 \cdot 70$ & $\mathbf{I} \cdot 77$ \\
\hline$\beta$-Cholesterol (mg/100 $\mathrm{ml}$ serum) & $\times 64.6$ & $5 \cdot 80$ & 3.00 \\
\hline$\beta$-Cholesterol (\%) & $8 r \cdot 7$ & $3 \cdot 63$ & 0.90 \\
\hline Ratio, cholesterol:phospholipid & 0.87 & 0.01 & $0.0 \mathrm{r}$ \\
\hline Triglycerides (mg/roo $\mathrm{ml}$ serum) & 120.9 & 13.53 & $4 \cdot 63$ \\
\hline
\end{tabular}

The following were the mean results for the estimation of the serum lipids: cholesterol $198 \cdot 5 \pm 4 \cdot 85 \mathrm{mg} / \mathrm{1} 00 \mathrm{ml}$; phospholipid $221 \cdot 4 \pm 5 \cdot 73 \mathrm{mg} / \mathrm{r} 00 \mathrm{ml}$; the cholesterol: phospholipid ratio $0.87 \pm 0.01 ; \beta$-cholesterol $164.6 \pm 5.80 \mathrm{mg} / \mathrm{ro0} \mathrm{ml}$; triglycerides $\mathrm{I} 20.9 \pm \mathrm{I} 3.53 \mathrm{mg} / \mathrm{ro0} \mathrm{ml}$. Inter-individual correlations were sought between the variables listed in Table I but many were found to be non-significant. However, the 
more important correlations are shown in Table 2. It may be seen that the fat intake expressed in calories, or as a percentage of the total calories, showed significant correlations with both serum total cholesterol and $\beta$-cholesterol, while there was no such correlation with $\alpha$-cholesterol. No attempt was made to find intra-individual correlations because the dietary assessments could not be made at the same time as the blood was drawn.

Table 2. Coefficients of correlation between serum fat levels and food intake, the latter expressed as calories, or as a percentage intake for twenty-four male adults in Antarctica

\begin{tabular}{|c|c|c|c|}
\hline & & $\begin{array}{c}\text { Correlation } \\
\text { coefficient } \\
(r)\end{array}$ & Significance \\
\hline Total cholesterol an & $\begin{array}{l}\text { Total calories } \\
\text { Fat calories } \\
\text { Carbohydrate calories } \\
\text { Protein calories } \\
\% \text { Intake of fat } \\
\% \text { Intake of carbohydrate } \\
\% \text { Intake of protein }\end{array}$ & $\begin{array}{r}0.39 \\
0.53 \\
0.18 \\
0.38 \\
0.49 \\
-0.37 \\
0.17\end{array}$ & $\begin{array}{l}\text { NS } \\
P<0.01 \\
\text { NS } \\
\quad \text { NS } \\
P<0.05 \\
\quad \text { NS } \\
\quad \text { NS }\end{array}$ \\
\hline$\beta$-Cholesterol and: & $\begin{array}{l}\text { Fat calories } \\
\% \text { Intake of fat }\end{array}$ & $\begin{array}{l}0.58 \\
0.56\end{array}$ & $\begin{array}{l}P<0.01 \\
P<0.01\end{array}$ \\
\hline \multicolumn{2}{|c|}{$\beta$-Cholesterol $(\%)$ and $\%$ intake of fat } & 0.47 & $P<0.05$ \\
\hline \multicolumn{2}{|c|}{$\begin{aligned} \text { Ratio, cholesterol to phospholipid and: } & \begin{array}{l}\% \text { Intake of fat } \\
\text { Fat calories }\end{array}\end{aligned}$} & $\begin{array}{l}0.78 \\
0.53\end{array}$ & $\begin{array}{l}P<0.001 \\
P<0.01\end{array}$ \\
\hline \multirow{2}{*}{\multicolumn{2}{|c|}{$\begin{array}{l}\text { Phospholipids and } \% \text { intake of fat } \\
\alpha \text {-Cholesterol and } \% \text { intake of fat }\end{array}$}} & 0.45 & $P<0.005$ \\
\hline & & 0.12 & NS \\
\hline
\end{tabular}

NS, not significant.

\section{DISCUSSION}

The mean cholesterol and phospholipid levels for the group as a whole agree with the findings of other workers (Barker, 1939; Bronte-Stewart, 1959; Peters \& Man, 1943; Tanner, I95I). The standard error of \pm 4.85 for total cholesterol also agrees with collected values (Peeler, Hepler, Kinney, Cisler \& Jung, I950). The positive correlations between cholesterol levels and the total fat intake as well as the fat intake expressed as a percentage are of interest. Evidence has been presented based on comparison of population groups which supports the contention that the major dietary factor which affects the serum cholesterol is the total fat intake or the percentage fat intake. A linear relationship was demonstrated between the mean serum cholesterol level and the percentage of the total calorie intake supplied by fat in epidemiological studies of these large population groups (Keys, I957). That Morris et al. (1963) were unable to find a significant statistical correlation between individual dietary fat intake and plasma cholesterol in ninety-nine bank men has already been stated. Further, a negative correlation was reported by the same authors between the serum cholesterol and carbohydrate intakes, but this was not significant. This finding is similar to the present results in that cholesterol was also found to have a negative correlation with carbohydrate intake $(r=-0.37$ : not significant). The main difference between the statistically non-significant results of Morris et al. (1963) and the 
significant result of our survey is that all evaluations were the average of several assessments made over a prolonged period of time; for the lipids this was the mean of twelve measurements, and for the food intake, each person was assessed eight times. Thus, because all measurements were spread apart, the seasonal variations were taken into account (Antonis et al. 1965; Easty, 1967), and at the same time the intraindividual variations were removed.

Other investigators have failed to substantiate the pre-eminence of the total dietary fat in individuals. In the first instance, the effect of reducing the fat intake on the serum lipid level was often disappointing, very severe restriction being necessary to produce a moderate decrease in serum cholesterol levels. Anderson \& Keys (1953) achieved a fall in serum cholesterol of only $21 / \mathrm{mg} 100 \mathrm{ml}$ by reducing the fat content of the diet from 140.0 to $70.0 \mathrm{~g}$ (i.e. $37-18.5 \%$ of fat calories) for 4 weeks. Later reports have favoured the degree of saturation as being of more importance in influencing the serum lipid levels (Bronte-Stewart, 1958). The fat intake at Halley Bay was highly saturated and oils were not used in cooking. The fat intake during the expedition was estimated to be about $80-90 \%$ saturated, and it is probable that this proportion did not vary over the year. This suggests that it was because of the absence of changes in the degree of saturation that a significant correlation was found.

That the serum triglycerides showed no significant correlation with the fat intake was to be expected owing to the high variability of these levels. Reports have varied over the relationship between skinfold thickness and serum lipids; some groups have found a positive correlation in certain situations (Albrink \& Meigs, 1964) while others have failed to detect any correlation whatsoever (Thomas \& Garn, 1960). The absence of a significant correlation in the present investigation would agree with the latter findings.

The generous help and encouragement of the late Dr Arnold Antonis, recently of the South African Institute of Medical Research, Johannesburg, and of Dr O. G. Edholm, Director of the Division of Human Physiology, Medical Research Council, Hampstead, London, is gratefully acknowledged.

\section{REFEREN CES}

Albrink, M. J. \& Meigs, J. W. (I964). Am. J. clin. Nutr. 15, 255.

Anderson, J. J. \& Keys, A. (1953). Fedn Proc. Fedn Am. Socs exp. Biol. 12, 169.

Antonis, A. (1959-60). F. Lipid Res. I, 485 .

Antonis, A., Bersohn, I., Plotkin, R., Easty, D. L. \& Lewis, H. E. (1965). Am. F. clin. Nutr. 16, 428.

Barker, N. W. (1939). Ann. intern. Med. 13, 685 .

Bronte-Stewart, B. (1958). Br. med. Bull. 14, 243.

Bronte-Stewart, B. (1959). Postgrad. med. F. 35, r98.

Burstein, M. \& Samaille, J. (1958). Path. Biol., Paris 34, 540.

Easty, D. L. (1967). Br. F. Nutr. 21, 7.

Fiske, C. H. \& Subbarow, Y. (1925). F. biol. Chem. 66, 375 .

Keys, A. (1957). F. Am. med. Ass. 164, I912.

Lewis, H. E. \& Masterson, J. P. (1963). Lancet i, Ioog.

McCance, R. A. \& Widdowson, E. M. (1946). Spec. Rep. Ser. med. Res. Coun. no. 235.

Mendelsohn, D. \& Antonis, A. (1961). J. Lipid Res. 2, 45.

Morris, J. N., Marr, J. W., Heady, J. A., Mills, G. L. \& Pilkington, T. R. E. (1963). Br. med. F. i, 57 I. 
Norman, J. N. (1965). Br. Antarctic Surv. Bull. 6, т.

Pearson, S., Stern, S. \& McGavack, T. H. (1953). Analyt. Chem. 25, 813.

Peeler, A. L., Hepler, D. E., Kinney, V. M., Cisler, L. E. \& Jung, F. T. (1950). Y. appl. Physiol. 3, I 97.

Peters, J. P. \& Man, E. B. (1943). F. clin. Invest. 22, 707.

Sperry, W. M. \& Webb, M. (1950). F. biol. Chem. 187, 97.

Tanner, J. M. (1951). F. Physiol., Lond. rr5, 37r.

Thomas, C. B. \& Garn, S. M. (1960). Science, N.Y. 13I, 42. 